\title{
Initial part of longitudinal research on psychological and social adaptation including personality problems with Polish immigrants in Canada
}

\author{
Bogdan Pietrulewicz ${ }^{1,2 \cdot A, C, D}$, Peter Skeris ${ }^{3 \cdot B, D, G}$, Aleksandra Winter ${ }^{1 \cdot D, E, F}$ \\ 1: Kazimierz Wielki University in Bydgoszcz, Poland \\ 2: Laval University, Canada \\ 3: University of Toronto, Canada
}

\section{BACKGROUND}

The psychology of personality is cognitively one of the most interesting fields. In its full extent it tries to correspond to questions concerning the individual and his or her psychological life. Different personality variables manifest themselves in human everyday actions, and affect decision making and, along with intelligence, the way of adaptation to new environmental conditions.

\section{PARTICIPANTS AND PROCEDURE}

The presented work is a result of the initial longitudinal examination conducted in the second half of the 1980s on a group of 44 Polish immigrants to Canada. The second part of this study is continued on the same sample of respondents after 25 years.

\section{RESULTS}

The emigration waves caused by economic transformations in the eighties, just as is happening currently, in the country of origin grew to huge numbers. It shows the interactive process of changes taking place not only in society but also in the notion of the individual. Adaptive problems show themselves in all aspects of emigrants' lives. Motivation, discrimination, employment, frustration and mental health become the resultant of personality factors manifested in the ways of adaptation to new, extremely different conditions of everyday life.

\section{CONCLUSIONS}

This examination, in spite of the time in which it was conducted, is gaining in value, particularly at present. In our times we have also observed mass emigration of young, educated citizens who, similarly to the emigration of the 1980s, are coming across the same adaptive problems.

KEY WORDS

immigrants; adaptation; personality problems

CORResPonding AUthor - Prof. Bogdan Pietrulewicz, Kazimierz Wielki University in Bydgoszcz,

Poland, e-mail: psychologiaukw@hotmail.com

AUthors' CONTRibution - A: Study design - B: Data collection - C: Statistical analysis - D: Data interpretation .

E: Manuscript preparation · F: Literature search · G: Funds collection

to CITE this ARTICLE - Pietrulewicz, B., Skeris, P. \& Winter, A. (2013). Initial part of longitudinal research on psychological and social adaptation including personality problems with Polish immigrants in Canada. Current Issues in Personality Psychology, 1, 62-73. 


\section{BACKGROUND}

There are few studies that touch on such problems with a methodological perspective. The presented initial research has much value as a first-hand material and as a comparative one.

Due to the continuation of this research, our thesis remains accurate and is also the best start point for the following comparative study.

In the 1980s Canada accepted 55 thousand emigrants from Poland. It was only a part of the great wave of migration from Poland, which spread across the country as a result of the difficult transformations of that decade. Formally, contemporary statistics did not take into account Polish people staying in Canada on a temporary basis, or waiting for a residence permit, or the great number of applications submitted at consular institutions in Western European countries and in Poland.

It was possible to state that the emigration became one of the basic socioeconomic problems for Poland and Canada. The results of surveys in Poland (then unofficial) showed that every second young person had considered emigration. What is more, almost the half of the population of Canada are descended from families of emigrants of the post-war period or from those who arrived directly from another country. Everything pointed at the fact that in the following years the situation in both countries would not change. Economic conditions in Poland had induced people to seek sources of income abroad. Population forecasts of Canada at that time indicated the need for immigration in order to protect the workforce from progressing ageing and quantitative reduction.

Emigration on an individual scale manifests itself with accumulation of stressful experiences for people subjected to sudden environmental changes (Carson, Bytcher \& Mineka, 2000). In our examinations of the newest wave of immigrants we tried to reconstruct the individual definition of situations of people arriving in Canada, their experience and expectations, and to observe typical manners of problem solving. Emigration requires social integration in society as a whole, which causes changes in attitudes also to people with mental illness (Pietrulewicz \& Wolska, 2008). These expectations in combination with the attitudes of the local population and their institutions caused adaptive problems.

Adaptation on an institutional level was dictated by the significant size of the immigration and the change in attitudes towards newcomers on the part of the existing population. In response to significant population movement of the countries, changes in institutions of both countries took place. In the case of Canada, adjustment of the institutions was an element of the process of forming a young statehood and a significant slogan for politicians striving for votes.
From this point of view, we were prone to consider adaptation of the immigration new wave as a process of mutual adaptation of the arriving immigrants and the institutions of the country in which they settled.

The duality of the adaptation process became particularly distinct in the context of earlier waves of immigration from Poland, already constituting a fragment of the local society. In fact comparisons with the conditions met by the Polish people arriving in Canada before World War II and soon after it became a frame of reference for the evaluation of the behaviours and expectations of new immigrants. Circles of the Polish community abroad in Canada had significant histories and visible achievements during the examination. Polish people arriving in this country had already found institutions of the Polish community abroad and expectations of them, which were and still are one of the factors shaping their immediate surroundings. Therefore, mutual adaptation of all sorts of immigration waves from Poland was also an element of Polish people's adaptation in Canada.

\section{PARTICIPANTS AND PROCEDURE}

A questionnaire survey that included the group of immigrants after 1980 was conducted in the first half of 1988 and after almost 25 years in 2013 and is still unfinished. The questionnaire, which took 1.5-2 hours to fill in, contained 80 questions in a few basic sections: conditions of leaving Poland and arriving in Canada, employment status, existential conditions, psychophysical state, evaluations associated with the stay in $\mathrm{Ca}-$ nada and the attitude to the environment of the Polish community abroad and Canada as whole.

The questionnaire survey included a group of 44 respondents selected on the principle of the stratified sam-pling, which was supposed to enable the registration of different reactions of social-professional categories of immigrants. Providing for the representative nature of the sampling created great methodological and practical problems. There was no complete register of new immigrants at the time of the survey and the structure of the population could have been reconstructed only on the basis of the results of the general census and data of immigration authorities.

In the pilot research we aspired mainly to register the types of problems, characteristic situations and people's reactions. When the follow up survey is completed we will be able to compare results.

Apart from survey data we used statistical data, unofficial interviews with the representatives of recent immigrants and social employees providing services for immigrants. We did not omit press materials being published at that time in the newspapers of the Polish community abroad, which throw light on the situation of Polish people settling in Canada. 
On account of the small size of the sampling, we resigned from tests of the significance of differences and concentrated mainly on classification and qualitative analysis. It is also important to remark that both initial and contemporary surveys were/are made on the same group of immigrants using the same method.

\section{SOCIAL AND ECONOMIC SITUATIONS IN POLAND AND CANADA}

In Canada it was possible to distinguish three immigration waves, having different personality implications: pre-war emigration mainly from poor agricultural lands; post-war soldiers' immigration from the army of Anders, from which many came out of Soviet labour camps, travelled the war trail across the Middle East and took part in the Italian campaign; some of the incomers in the 1940s and 1950s, who returned from German forced labour and prison camps to Canada. The next surge of immigration took place in relation to the economic crisis in Poland in the 1970s and with the formation of the "Solidarity" movement fighting for political freedom, including also the right to have contact with western countries.

The 1970s, preceding the examined wave of emigration, were characterised by increased propaganda of the success and seeming improvement in the standard of living caused in large by the allocation of foreign monetary loans for the import of consumer goods. Further repressive action towards the democratic movement for fundamental democratic reforms was accompanied by the loosening of control of different areas of social life in the "Gierek" times. Easier access to trips abroad caused intensified comparisons to the West and increasing aspirations among the post-war generation in Poland.

The announcement of martial law, suppression of the opposition and a harsh economic crisis brought an entire generation of Polish people to the point of collapse regarding their expectations. Simultaneously it was a generation brought up in the propaganda of the welfare state, which was supposed to secure collectively a high standard of living. Increased anti-Western propaganda caused - on the principle of the rejection - the creation of the image of countries with perfect competitive economies as places where a high standard of living was attained automatically.

Canada, similarly to other Western countries, experienced a period of favourable development in the 1950s and 1960s. The oil crisis in the middle of the 1970s caused a slowdown of the economic situation and intensification of the recession, with its climax in Canada in 1982. Trade cycles found their reflection in the immigration policy. Canada accepted 218.5 thousand immigrants in 1974 (the second largest number in the post-war period) but a systematic limitation meant that this number had fallen to 84.5 thousand by 1985 .
Moreover, the mid 1970s coincided with ending of the Vietnam War and the intensified problem of refugees from Southern Vietnam. In 1980-1986 almost 74 thousand refugees from Vietnam were accepted, which constituted $9.8 \%$ of all immigrants in Canada. The second largest group were newcomers from Great Britain (8.2\%), followed by India (6.2\%), the Philippines (4.3\%) and Poland (4.2\%). In later years immigration from Hong Kong (threatened with the takeover by China) grew from 6.8 thousand people to almost 23 thousand annually and took the first place. In 1988/1989 Polish people were the second largest group of immigrants totalling 10.6 thousand.

Canada was characterised by an uneven pace of economic development. Moreover, the regional differences were exacerbated by cultural and legal differences between provinces dominated by English-speaking and French-speaking residents. Quebec, aspiring for an increase in its population, demanded the right to determine the level of immigration independently. However, the favourable economic situation in Ontario, especially in the area of Toronto, supported the inflow of the population into these regions. Toronto, as Canada's largest city, still has the largest number of immigrants, including immigrants of Polish origin.

\section{IMMIGRATION STATISTICS}

In the general census of 1986123,120 people declared Polish as their mother tongue. There were 222,260 people of Polish origin (both parents being Polish); moreover, 389,840 people declared that one of parents was of Polish origin. Altogether 612,105 people declared at least partial Polish origin. 22.2 thousand people of Polish origin inhabited the following provinces (in thousands):

1) Ontario - 117.5,

2) Alberta - 28.5,

3) Manitoba - 22.0,

4) British Columbia - 19.3,

5) Quebec - 18.8,

6) Saskatchewan - 13.3,

7) Nova Scotia - 1.8.

The greatest number of Polish people could be found in the following cities:

1) Toronto - 51.390 ,

2) Montreal - 16.395,

3) Vancouver - 10.650,

72,995 people declared Polish as their mother tongue in Ontario in 1986.

Level of education of residents in Ontario in 1986 who were born in Poland:

1) grades $9-27,760(34.8 \%)$,

2) grades $9-13-21,410(26.8 \%)$,

3) vocational schools $-2,835(3.6 \%)$,

4) college - 13,890 (17.5\%),

5) began studies - 13,840 (13.3\%). 


\section{EMIGRATION DIRECTIONS}

In the entire post-war period the possibility of legal emigration from Poland was limited. The majority of people used the right for temporary departure from Poland in order to make an attempt to legalizing their status outside the country. It closed the way back to Poland due to the sanctions for overstepping regulations of the Polish People's Republic. Tourist trips with the intention of leaving the country permanently reached their peak in the 1970s. People turned to refugee camps in Australia, Italy, Germany and Sweden. Many people went to France, Greece and even to Israel. Only from there were efforts being made to obtain a permanent residence permit in the USA, Canada, the Republic of South Africa or Australia. Applications were usually sent to a few countries simultaneously.

Canada had the reputation of the most open country and many reached it, often when they did not obtain a residence permit for the USA or Australia. The number of people went to Canada for a temporary stay and searched for means of legalising their stay while they were there. This procedure took from a few months to a few years and, in case of the staying in refugee camps, it was full of stressful experiences.

\section{REASONS FOR EMIGRATION}

From 44 respondents 5 gave political arguments as the main justification for emigration. Here are several answers to the question regarding the reason for their departure from Poland: "Shock caused by the Martial law. I felt like I'd been slapped". "The communist system didn't suit me". "Depriving my husband of work right after implementing the state of emergency". "I lost my job at a school as a result of the so-called verification of teachers".

The vast majority of the replies referred to difficult economic conditions. To a certain extent these reasons alternated with criticism of the political system. The cultural isolation of the country caused by ideological accounts was given once, and various reasons of a personal nature including the need to experience adventure and trying out in a new land were given a few times.

\section{SPATIAL MOBILITY}

Of the 44 respondents from the questionnaire survey, people gave their last place of stay before their arrival in Canada as follows: Poland - 10, Austria - 12, Germany -3 , Italy -7 , France -1 , USA -3 and other countries -8 . The largest groups arrived in Canada from Poland, Austria and Italy.

Until the time of conducting the survey the trend of settling in Ontario and Toronto was predominant.
Attempts to disperse settlers who used government support by fixing the place of their first settling did not bring the expected results. Only a sudden increase of house prices in Toronto and the lack of free flats contributed to a reduction of the inflow of the population and the secondary migration of residents of Toronto to other cities.

A total of 35 persons gave the Toronto metropolis as their first place of settling in Ontario, 1 - another major city and 2 - smaller cities. Six respondents arrived from outside Ontario: 4 from major cities and 2 from other towns.

Increased spatial mobility is always a result of seeking suitable working conditions and settling. After their arrival in Toronto 12 respondents remained at the same address, 14 moved once, four -2 times, eight -3 times and six - more than 3 times.

\section{PROFESSIONAL ADAPTATION}

Career is one of the crucial factors of adaptation in a new country. It is one of the basic meters of success in life, economical security prestige and the important field of self-realisation of the individual and exemplification of personality preferences. Finding a proper job is the first purpose of arriving in a new country.

Confrontation with the new social system takes place throughout the career. Entering into contact with other people in the workplace establishes effective intercommunication with them, understanding their social roles and adapting their own behaviour to new expectations. In this context, contact with different work ethics is observed (Goldberg, 1981).

The fundamental difference of the new labour market is the attitude towards work as scarce good. The ideology of the Polish People's Republic, as a welfare state, guaranteeing full employment, deprived people of a lot of features indispensable for applying for a job in competitive conditions. Adjustment to them required applying different strategies of being placed on the labour market.

Initially it was possible to distinguish a few basic orientations or the strategy of professional adjustment:

a) taking any available work with the intention of gradual improvement to find work more suitable to one's qualifications and aspirations;

b) putting off gainful employment with hope for the "right" job. In the meantime improving their linguistic and professional qualifications;

c) self-development and possible change of occupation;

d) creating one's own place of employment, mainly by establishing a new company;

e) transferring professional aspirations to the field of non-business activity (artists earning with other 
work so that they could devote themselves to artistic activity in their free time);

f) withdrawal from the market: in the case of women returning to the household, becoming unemployed or dependent on public allowance (welfare), early retirement, sometimes obtaining financial resources by means colliding with laws or customs.

\section{PROFESSIONAL STRUCTURE}

In response to the question about the acquired profession in Poland, none of the respondents described themselves as unskilled workers or as farmers. Two described themselves as skilled labourers; six as technicians and clerks with secondary education; one person had a craft business; twenty-three persons (50\%) declared higher education, complete or incomplete; and three persons did not answer. The data confirmed the presumption that people who left Po- land had higher qualifications. This is also confirmed by the data of the general census and the statistics of immigration authorities (Table 1).

Details of the general census about the professions of people residing in Ontario, aged over 15, who declared Polish as the their mother tongue were included in the first column. Data of immigration authorities regarding immigrants from Poland arriving in 1986, and professions declared by them were included in the second column. The comparison shows that there are twice as many representatives of engineering professions amongst immigrants than amongst permanent residents. On the other hand, in both groups there is a small percentage of farmers and representatives of the professions from forest management and the mining industries, where Polish immigrants were usually appointed before the war and right after its end. Amongst immigrants of that time, there were a similar number of health service employees, smaller number of clerks and much smaller number of ser-

Table 1

Professions of residents and immigrants, 1986, Ontario

\begin{tabular}{|c|c|c|c|c|}
\hline \multirow[b]{2}{*}{ Administration } & \multicolumn{2}{|c|}{ Residents' profession } & \multicolumn{2}{|c|}{ Immigrants' profession } \\
\hline & 3855 & $9.6 \%$ & 17 & $0.6 \%$ \\
\hline Engineer, natural sciences, mathematics & 2880 & $7.1 \%$ & 469 & $15.4 \%$ \\
\hline Clergy & 600 & $1.5 \%$ & 44 & $1.4 \%$ \\
\hline Education & 1620 & $4.0 \%$ & 134 & $4.4 \%$ \\
\hline Healthcare & 2040 & $5.0 \%$ & 177 & $5.8 \%$ \\
\hline Artistic professions & 535 & $1.3 \%$ & 65 & $2.1 \%$ \\
\hline Sport, leisure organisation & 40 & $0.1 \%$ & 13 & $0.4 \%$ \\
\hline Clerical profession & 5520 & $13.7 \%$ & 274 & $9.0 \%$ \\
\hline Trade & 2615 & $6.5 \%$ & 53 & $1.7 \%$ \\
\hline Services & 4900 & $12.1 \%$ & 120 & $3.9 \%$ \\
\hline Farming, breeding & 970 & $2.4 \%$ & 56 & $1.8 \%$ \\
\hline Fishing, hunting & 0 & $0.0 \%$ & 4 & $0.1 \%$ \\
\hline Forestry & 110 & $0.3 \%$ & 0 & $0.0 \%$ \\
\hline Extractive industry & 85 & $0.2 \%$ & 21 & $0.6 \%$ \\
\hline Processing industry & 1890 & $4.7 \%$ & 64 & $2.0 \%$ \\
\hline Operation of machine tools, lathes & 2125 & $5.3 \%$ & 185 & $6.0 \%$ \\
\hline Assembly line, toolmakers & 5530 & $13.7 \%$ & 415 & $13.6 \%$ \\
\hline Building industry & 1860 & $4.7 \%$ & 270 & $8.3 \%$ \\
\hline Transportation & 690 & $1.7 \%$ & 109 & $3.5 \%$ \\
\hline Factory storeman & 1055 & $2.6 \%$ & 24 & $0.7 \%$ \\
\hline Operation of building machinery, etc. & 395 & $1.0 \%$ & 20 & $0.6 \%$ \\
\hline Other professions & 895 & $2.2 \%$ & 508 & $16.6 \%$ \\
\hline Total & 40300 & $100.0 \%$ & 3051 & $99.3 \%$ \\
\hline
\end{tabular}


vices employees. However, there were more builders. It should be taken into consideration that decisions of employment could be different from the declaration of preferred professions. Moreover, the ranking of immigration authorities was vague at that time due to the fact that $16.6 \%$ of people were not qualified in the previously mentioned professional categories. Six percent of residents managed their own companies.

\section{PROFESSIONAL MOBILITY}

In the 1980s a slight professional mobility, resulting from the low susceptibility of the system to technological and organisational changes, was visible in Poland. In the sampling 27 people gave their last profession the same as the previous profession; 3 people worked in a different profession, but categorised it in the same category of activity; 5 people performed completely different work than previously; 2 established their own company; and 5 people failed to answer.

In the sampling only one person stated that he or she had never had a career job in Canada. It shows clear noticeable need to start work as soon as possible and to fulfil their aims through work.

\section{FIRST JOB}

Twenty respondents (45.5\%) declared unskilled work when asked about their first job in Canada. Four people performed qualified work, two people worked as technicians, one as a craftsman and one as a clerk. Eleven people (25\%) were employed as specialists in fields that required training at colleges level. There was a lack of data in four cases.

It is striking that almost half of the people with a university education found their first job at an appropriate level for their qualifications. Simultaneously, only 5 of 23 respondents with higher education performed their first job as unskilled workers. This suggests that more educated people had better chances of finding employment on the level of their qualifications because of better adaptation of their professions to the market's demands or better abilities in applying for a job. It could mean that the part of them deterred from taking casual work and sought something better (three people did not declare their performed work).

In response to the question about their first paid work in Canada 16 respondents answered that they started less than a month after arrival, 2 - less than 2 months and 4 - less than 3 months. Four respondents found a job almost half a year after their arrival, 8 - a year after and 5 people started later. Five respondents failed to answer.

After their arrival in Canada 26 people $(59.1 \%)$ worked full time, 5 - full-time for most of the time and 5 worked only occasionally. Three people were unemployed for the majority of the time. No data was acquired from 3 respondents.

In the sampling 10 people performed unskilled work (domestic help, work in a fast food bar, at a cashier's window, nursing help) and 11 people performed qualified work. Nobody declared that they worked as a technician or craftsman. Eight persons worked in offices and 9 in positions requiring higher education. One person had their own company, and 5 did not have a career job.

\section{WORKPLACE}

When asked about the character of their workplace, 3 people declared work in a state-owned company, 7 - in a big production unit, 14 - in smaller private company and 2 - in their own company. Twelve respondents worked in "other" workplaces such as a retirement home, large accountancy company, insurance company, private company of average size, large design studio, private house (domestic help) or university. This example shows the great diversity of institutions offering places of employment to new immigrants at that time. Simultaneously, a greater role is stated in employment by private companies. A considerable amount of small businesses already existed in Toronto, some from previous Polish immigrants, and the owners employed their fellow countrymen.

\section{DEMAND FOR PROFESSIONAL QUALIFICATIONS}

On arrival in Canada many people stated that there was little demand for their qualifications. The jobs available were usually onerous, low paid and not requiring qualifications. These workstations were dismissed by employees who found more beneficial positions. Skilled workers could find employment after basic training in the workplace.

The technical jobs on an average level were available after mastering elementary language skills and verification of qualifications. At college level it was possible to perform technical jobs only after receiving a diploma and completing an internship in Canada. The criteria for the validation of a diploma were not homogeneous and were often inconsistent. Completing supplementary courses depended on the opinions and pressures of the professional environment. For some professions, for example doctors, issuing permits for the practice was drastically limited due to the excess of candidates.

In general, qualifications that were less dependent on language skills were simpler to place on the labour market. The majority of jobs based on humanistic specifications were classified as jobs with no demand 
on the market. Artistic jobs not only belonged to this group but were also less supported by government subsidies than in Poland and in other European countries. Apart from the category of outstanding individuals, emigration for the majority of representatives meant breaking with their current career, loss of status and often living on the breadline. This category of people was exposed to increased stressful influences.

\section{SOURCES OF INCOME}

In the first year of their stay in Canada respondents used different financial sources at the same time. Fourteen people used their own resources, and 29 people received income from paid work (6 people mentioned both categories simultaneously). Twelve people received government allowance for refugees and 3 listed relatives as a source of financial help.

Government help was an important factor which allowed the refugees to survive the interim period. People who were qualified received essential funds for the period of one year and attended free language courses. In the second year of the stay in Canada only one respondent used other forms of government assistance, and one person used unemployment benefits and welfare as the primary source of living. Some people consciously used social aid, which, moreover, entitled them to expensive medical benefits. It is possible to assume that they were not always willing to admit that they used this form of assistance due to the negative feedback associated with such situation.

\section{SATISFACTION FROM WORK}

Two people, when asked about their satisfaction with their performed work, stated that they were very dissatisfied with it, 11 - rather dissatisfied, 17 - rather pleased and 8 - very pleased. Six people gave no answer. Positive opinions prevailed from the majority of respondents.

Twenty people responded positively to the enquiry about improvement of working conditions in the current place of employment, whereas 13 people answered negatively. Eleven people gave no answer.

The evaluation of their own work is conducted in comparison with two main frames of reference: with previous work in Poland and with working conditions of acquaintances and people in a similar situation in Canada. After arrival in Canada the least attractive jobs were treated as a necessary evil and temporary situation. The first comparisons of earnings, even the lowest, were still favourable. With time, comparisons to Poland were no match for comparisons to other people working in Canada. As a result, new standards of evaluation appeared. The level of satisfactory earnings increased permanently.
People who previously had successful professional careers experienced considerable loss of status in the new place of employment as a rule. As a result, different rationalisations are activated to justify this situation (Marody, 1976). The most common were justifications of a political character (flight from a repressive system), treating the situation as temporary or sacrificing oneself for the family and children.

\section{OBSTACLES IN FINDING A JOB}

Amongst the obstacles listed as hampering the process of finding work the most frequently selected were (multiple choice allowed) lack of sufficient knowledge of language - 20 and lack of a Canadian internship 20 . Some mentioned a lack of experience in preparing job applications -6 , and a lack of adequate professional qualifications - 7. In two cases overqualification was mentioned Experience in this area meant that some people applying for a job not requiring special qualifications concealed the fact that they had a university degree.

\section{STATUS DISCREPANCY}

Employing new immigrants led to many cases of considerable status discrepancy. It was not uncommon that graduates of universities performed physical labour or provided simple services. However, it was not a phenomenon limited to newcomers from other countries. Fast reallocations on the labour market meant that graduates of local colleges were also often in such a situation.

In postindustrial society the traditional criteria of divisions disappear and without new ones, money and consumption are treated as substitutes for social diversity.

\section{PROFESSIONAL INDEPENDENCE}

Uncertainty on the labour market forced many people to seek various means of becoming independent from the economic situation and organisational changes in workplaces. The simplest way to gain financial independence was a periodic increase in workload. In many cases people took on extra jobs, often to physical breaking point.

Improving professional qualifications was treated as natural protection against loss of work, similarly to re-skilling for new professions. Some employed people took on occasional work in other professions (real estate agents, providing periodic services). With time these occupations transformed into the main source of income for some people.

A business start-up was the most frequent solution for the problem of employment restrictions. Authori- 
ties encouraged this idea and supported smaller companies. Some of them provided services within the same language group.

\section{MENTAL HEALTH}

Leaving a home country is connected with leaving its environment as well as loss of the support which it ensures. Settling in a new country, first phase emigrants face feelings of alienation, loneliness and a drastic lowering of their standard of living. The necessity for adjustment to the new environment causes an increase in stress levels. It often exceeds the level of the individual tolerance and causes psychophysical disorders of various degrees (Carson et al., 2000). Possible disruptions of the psychophysical balance alone become a factor hampering adaptation.

Psychiatrists observing the behaviour of new immigrants describe typical reactions to the new situation. In the first period after their arrival people feel euphoria as a result of reaching the target country. New surroundings cause super-excitation of the individual, confronted as they are with an excess of stimuli. As a result they deal with mobilisation of the system and a burst of energy, lasting from a few hours to a few days. The individual experiences unusual reactions such as déjà vu - the impression that they have seen the new surroundings and people somewhere before.

This reaction is explained as an involuntary attempt to interpret unknown stimuli through remembered schemes. A decline in activity follows the period of super-excitation. The individual makes a sober evaluation of his or her abilities and attempts to solve the initial problems (Ross \& Nisbett, 1991).

Sometimes after the tide of euphoria, depression appears. Deeper states of depression manifest themselves with apathy and psycho physiological disorders: headaches, disorders of the digestive tract and insomnia. Behavioural changes were also observed, e.g. shoplifting in the case of people who had never displayed such tendencies.

General home sickness causes marital misunderstandings, especially if one person wants to return to their home country.

Frustration and conflicts with the environment cause intensification of the reaction of a paranoid character. Some people become excessively careful and suspicious or react with aggression to the alleged attack. In extreme situations delusions can develop into a persecution complex (ideas of reference) in which bystanders seem hostile. Deep depression and paranoia sometimes end with a suicide attempt (Carson et al., 2000).

Depression often remains undiagnosed until the moment when deeper disorders appear.

\section{HEALTH CONDITION}

To the question about their health condition, 14 respondents answered that it was very good, 25 said it was good and 5 stated that they had certain problems. These statements would point to the fact that the vast majority arriving in Canada would like to see themselves as people in good medical condition, ready to make increased effort in order to overcome expected problems.

To the question about how their medical condition had changed for the better during their stay in Canada, 4 people answered that it had changed for better, 26 did not notice any changes and 13 respondents admitted that their medical condition had deteriorated. One person fail to answer.

Further questions concerned stress symptoms such as constant tiredness, headaches, insomnia, chest pains or allergies. Their state was compared immediately after their arrival in Canada and later (after a few months, years). Ten respondents stated that in the beginning they still felt tired, while 14 people noticed this state in the last period before the examination.

Intensification of constant tiredness could have been a reflection of increased occupational activity and the burden of other duties, including learning a new language and profession. Five respondents experienced headache "sometimes", and 2 "often". This complaint was registered more often in the later survey: 14 people complained about headache "sometimes" and 3 "often". At the beginning of their stay 3 people recorded insomnia "sometimes" and 4 "often". Recently 1 person had sleeping disorders "sometimes" and 5 "often". Chest pains were recorded at the beginning "rarely" or "occasionally" by 6 people, while 9 reported this in the more recent survey. In the beginning the respondents had allergies "rarely" -3 people, "sometimes" -3 and "often" -3 , while the later survey revealed "rarely" - 5 and "sometimes" -5 .

This data does not present an explicit trend but suggests a certain rise in the strength of intensification of these symptoms. Because of the small scale of the sample, taking the variable of time into account was not possible. Monitoring data would induce an accumulation of stress, and symptoms associated with it came after a short stretch of optimistic contact with the new country of residence. With time, adjustment to the new environment developed in the form of improved linguistic contact and more stabilised financial and professional status. Moreover, there was a group of people among whom the venting of frustration took place and for whom it was possible to get emotional support. These factors supported the disappearance of complaints and, consequently, the development of personality (Gasiul, 1986). On the other hand, there was a rise in the professional burden caused by the aspiration for fast improvement of 
the financial situation. Excessive career burden could cause secondary intensification.

Frame of mind and general medical condition are also influenced by the mental state of the individual, which can be also treated as the consequence of the adjustment to new conditions. Homesickness and longing for close friends and family is perhaps the most common effect of emigration. However, states of doubt and resignation that can affect the state of mind in disadvantageous ways can be the result of encountered problems.

Five people said that they were not homesick for Poland, 15 said that they felt this "rarely", 17 "sometimes" and 4 "often". These declarations should be interpreted in the context of the rule demanding "male" behaviours and emotional independence. However, 20 people still admitted that homesickness occurred with varying frequency.

Doubts about whether living in Canada would be successful occurred "sometimes" in 11 people and "often" in 7 people. Feelings of loneliness are a related indicator of maladjustment. Some people feel a lack of friends and emotional support because of their psychological predispositions to their situation in life. The following number of respondents complained about loneliness: 10 people "sometimes" and 9 people "often".

The question about feeling that "living in Canada doesn't make sense" was treated as an indicator of depression and the breakdown of positive attitude. Six people stated that such thoughts obsessed them periodically, and 2 people said that this occurred "often". Although people sustaining periodic breakdowns were in the minority in the examination, this phenomenon should not be omitted on account of the dangers caused by deepened depression.

\section{SUBSTITUTE FORMS OF STRESS REDUCTION}

A lack of any possibility to relieve stress causes defence reactions in the form of aggression, racial and ethnic prejudice, rejection of the culture of the target country, withdrawal from social life, limited social contact and escape into mysticism and bizarre forms of religiousness. Alcoholism and drug addiction can be listed in the same category of substitute forms of stress reduction (Ross \& Nisbett, 1991).

In certain circumstances the accumulation of stress causes a deeper collapse of the personality structure into illness. More permanent mental balance disorders require psychiatric care. Using psychiatric treatment is also a function of a particular social situation, ideas of the norm and pathology, the possibility of independent functioning of the patient. The decision to undergo treatment can be a result of environmental pressure (Nelson, 2002).
According to the observation made in the largest mental hospital in Toronto, Queen Street Mental Health Care, 40 years ago Polish patients were underrepresented at this institution. Since the second half of the 1980s the proportion as a proportion of the population numbers has been increasing. Dear and Taylor (1980) presume that more frequent use of mental hospital services might be the result of better education and reduced prejudice towards this institution, as well as increased possibility to use benefits offered by the system.

\section{POLISH OR CANADIAN OF POLISH ORIGIN?}

Polish people settling in Canada, called Polonia (although many do not identify with this name), are a natural frame of reference for new immigrants. In fact, one of the reasons why Canada is such a popular country to move to, in particular Ontario and Toronto, is the awareness that big centres of the Polish community can already be found there.

Everyday observation and available data allowed the identification of a few typical reactions to the first contact between Polish people newly arriving in Canada and those who have already spent some time in the country or grew up there. It is possible to assign these mutual references to certain stages of mutual cognition and adaptation.

A) First contact gives rise to mutual interest and hopes to fulfil certain expectations. Newcomers expect help in solving existential problems, former expect recognising their role as hosts in the new area, their position and achievements.

B) Soon it comes to measuring different mentalities, views for life, hospitality, personal freedom, differences in taste.

C) Awareness of the differences in attitudes causes negative evaluations, stereotypes and mutual rejection. The older Polish community abroad is accused of a lack of insight into the problems of contemporary Poland, a mentality typical of the cultural ghetto, a lack of taste.

D) On the part of the settled Polish community abroad, reactions of mistrust and dislike of new immigrants are also created. They are suspected of excessive aspiration, a lack of respect for good work and a tendency to use social security that was earlier inaccessible. They are accused of a lack of patriotism and egotistical attitudes.

E) After a period of mutual separation, a secondary approach takes place on the principle of selective approval. Besides occasional contact and everyday workplace relations, there is contact during common celebrations, undertaking common actions of help for Poland and new immigrants and holding demonstrations against the government of the Polish People's Republic until the second half of the 1980s. 


\section{IDENTIFICATION WITH POLAND}

With time attitudes towards Poland change, at least in the sphere of linguistic change, but they are not immediately perceptible.

Respondents were asked whether they consider themselves to be Poles, Canadians of Polish origin or Canadians. The vast majority (38 people) stated that they regarded themselves as Poles. Six people chose the response "Canadian of Polish origin". It is possible to treat this second reply as an expression of aspiration, a desire to avoid the stereotype of "immigrant" and to be accepted by Canadians as quickly as possible.

Polish remained the dominant language, although in some cases intensive learning of English led to its distortion. Bilingualism in the meaning of free and correct usage of both languages was rare.

Despite a strong identification with the country of origin in the emotional sense, there was a gradual shift of focus and the polarisation of contents. Strong reactions to the country of origin as the mother country in which they grew up and where close friends and family had stayed, identification with the nation, and aspiring to gain independence, were accompanied by ambivalent attitudes towards everyday life and the reality associated with it. Contact with the country underwent rarefaction and information about changes became fragmentary.

New employment and acquaintances in Canada often caused confrontation with attitudes and evaluations critical toward Poland. Although originally they were rejected, it was possible to observe their partial involuntary acquisition. In many cases, entering new systems of prestige and evaluation meant distancing themselves from evaluations taken from Poland. As a result, a process of anchoring emotional postures took place in a few "relevant" aspects of the Polish situation, associated with such notions as: homeland, freedom, religion, culture and family, and a simultaneous disappearance or distance to values of everyday life.

Homesickness as a feeling which returned "often" for 4 people, "occasionally" - 17, "rarely" - 15, "never" - 5 and no data were collected for 2 people. Respondents expressed a longing for the country, close friends and family, the warmth of the human contact, family and familiar places. A dissimilarity of lifestyle in Poland was emphasised, its beauty in particular situations, the availability of leisure time, entertainment, the beauty of places and of the landscape.

Even though longing for one's home country becomes diminished with time, this phenomenon appears unevenly in some cases. It transpires that people who are abroad for years feel good in the temporariness of their decision and they are affected by radical change of mood when forced to make a decision about remaining in the foreign country permanently. There is also a presumption that people from cities, having looser contact with their families and a more absorbing career, adapt more easily (Skinner, 1953).

Certain aspects of professional self-realisation, in combination with feelings of reserve towards the Polish community abroad, gave rise to seclusion from Polish matters and external indifference towards them.

\section{ATTITUDE TO ORGANISATIONS OF THE POLISH COMMUNITY ABROAD}

New immigrants, as a rule, display signs of reserve towards traditional ways of spending leisure time and demonstration of membership of a particular national group. Twenty-five people did not participate in picnics and games, 8 reported that they attended such things "rarely", and only 4 stated that they participated "occasionally". Similarly, regarding artistic performances, displays of folk dancing, singing festivals, cabaret parties with teams making guest appearances from Poland, 11 people "did not participate", 12 people "rarely participated in them", 12 "occasionally" and 5 "often".

When asked about readings and meetings with interesting people, including representatives of the opposition from Poland, 19 people said that they "didn't participate", 16 reported attending such events "occasionally", 2 claimed "often" and for 7 people there was no data. These meetings were not held regularly and periods without such events came after periods of high-intensity of organisational activity.

Participation in gatherings to celebrate patriotic anniversaries, academies and marches was limited. Twenty-two persons stated that they "do not participate" and 7 said "occasionally".

Thirteen people also declared "occasional" involvement in organisational activity, 25 people stated that they "do not participate", and only 2 respondents were involved in organisations of the Polish community abroad.

The lack of the commitment to organisations of the Polish community abroad on the part of recent immigrants is a phenomenon often discussed by circles of the Polish community abroad. In this respect, waves of immigrants preceding the ones of the 1970s were characterised by a greater readiness to organise themselves and participate in community work. In part, the attitudes of new immigrants were justified by their negative experience brought from Poland, where participating in state-controlled organisations was compulsory. In part, it was probably also an effect of individualistic attitudes, a belief that individual and rapid effort to join Canadian society would ensure success and fulfilment of their aspirations.

Individualism can be derived from feelings of greater safety in comparison with immigrants of pre- 
vious waves, who were left to look after themselves, had no social security and in general met greater prejudice on the part of the native population. Therefore, their natural defensive reaction was to join together in unions of self aid and organisations fighting for their place in Canadian society. Immigrants of the 1980s indirectly use the reputation and institutional security gained by settling in Canada for a long time. In part, this attitude could also be dictated by different customs and habits regarding the style of work.

Political demonstrations organised in front of the consulate of the authorities of the Polish People's Republic in Toronto were less frequent and attractive. In the first elections for the Seym (Polish parliament), which led to the formation of Prime Minister Tadeusz Mazowiecki's government, about 2 thousand Polish residents from Toronto and its surroundings participated in protests. Actions such as hunger strikes in front of the consulate resulting from the refusal to grant exit visas for family members in Poland, were attended by the circle of people in and around the Polish Canadian Action Group. Similarly, appeals for help evoked a response for injured persons, and for the opposition in Poland, and fund-raising actions to help the country, including the election fund of the new government.

It was possible to observe partial engagement of a new generation in organisational activity. There were some signs: the Club of the Catholic Initiative, the circle of musicians and choir singers in the Musica Antiqua circle, the organisation of a conference titled Polish Community Abroad 2000, which gathered several dozen speakers, who represented organisations providing services for immigrants, scouts and artistic circles. Unofficial circles finally existed as groups acting by parishes accepting new immigrants and helping them to arrange their lives in a new country. In one Mississuaga parish they enabled the arrival of over a thousand families of new immigrants. The KPK bureau, financed by the government, operated in a formalised way, helping immigrants to deal with various formalities. In 1989 it arranged immigration visa applications for 6336 people.

This sign of new forms of activity in the environment was a development of the mass media. Four magazines were published regularly and a few other occasional titles were available in Toronto. There were several radio stations and two television channels.

\section{EVALUATION OF THE ORGANISATIONS}

When asked whether organisations of the Polish community abroad were of help to new immigrants, 4 people answered "yes, and what is more, to a high degree", 13 said "partly" and 19 people stated "a little”. Nine people failed to provide any data. Among the respondents there were 16 people who received help from an organisation of the Polish community.
The most popular area was help in giving basic information about formalities; 5 people stated that they had received help in finding a job. Courses and advice given by the Polish Technicians in Canada (STP), which helped dozens of people, were the most wellknown examples of organisational help. Courses in medical terminology for Polish doctors were of the same character. Efforts made by the STP took Polish engineers in numerous cases to recognise their professional qualifications, and friendly care of individuals helped them to adapt faster in their workplace.

A unique organisation of the Polish community abroad, which gained considerable popularity, was a parish co-operative bank Credit Union. The number of members exceeded 29 thousand and contributions amounted to $\$ 150$ million. Other smaller banks of this kind concentrated thousands of Polish people. Idea of a Credit Company that gathered contributions and made loans available to those in need succeeded throughout Canada, especially among emigrants.

The church remained a institution which gathered all circles of immigrants, above all the Roman Catholic Church, but also the National Church. In the sampling only 5 people said that they did not attend a church, and 7 people stated "rarely". The church fulfilled the conditions of an institution focusing the largest circles of society thanks to its form of participation, and for this reason it adopted secondary functions that were usually performed by other organisations.

Schools functioned next to parishes; groups helped in the arrival of more distant emigrants from Poland, there were readings and meetings, scout activities, games and parties. Priests and missionaries (Fathers Oblates in Canada) were natural leaders of communities of the Polish community abroad and initiators of campaigns by voluntary bodies: savings banks, retirement homes, schools and choirs.

There were even opinions that some of the Polish community abroad could disappear and the church would take over their functions out of necessity. The main restriction was a decrease in priestly vocations; as a result, clergymen arriving from Poland were entrusted with pastoral services.

\section{POLISH SCHOOLS}

There were 17 Polish schools by parish centre and Canadian schools in the area of Toronto. As part of the government program "Heritage Languages" they gained financial resources for teaching Polish. The Ontario act at that time ensured native language teaching if there was sufficient numbers of candidates in the given school. Polish schools acted outside the program of day schools and worked on Saturdays.

New immigrants had an ambivalent attitude toward them. In the test on 44 people, 19 had children of 
primary school age, but only 5 of them enrolled their children in Polish schools. Even though the majority of parents spoke Polish to their children, only some decided to send them to a Polish school. The reasons given were problems with transportation and poor standards of teaching. These schools were partly run by teachers who recruited themselves from the new immigration wave.

\section{NEW SHAPE OF THE DIASPORA}

The first noncommunist government in the postwar history of Poland meant the chance to close one chapter of the Polish story of emigration. This fact was of crucial importance for the self-definition of Polish communities outside the country and created hope for the deliberate co-forming of migration processes in the future. After twenty-five years, continued surveys on the adaptation aspects and changes which have happened among those years keep the discussion about recognising the problems accompanying immigration open for the continued development of the program of Polish institutions at home and abroad.

\section{RefERENCES}

Carson, R.C., Bytcher, J.N. \& Mineka, S. (2000). Abnormal psychology and modern life. Ney Jersey: Prentice Hall.

Dear, M. \& Taylor, S.M. (1980). External effects of mental health facilities. Annals, Association of American Geographers, 70, 342-352.

Gasiul, H. (1986). Cechy systemu ja jako kryteria oceny rozwoju osobowości. In: H. Gasiul (ed.). Problem osobowości we wspótczesnej psychologii (pp. 175-187). Toruń: Uniwersytet Mikołaja Kopernika.

Goldberg, L.R. (1981). Language and individual differences. The search for universals in personality lexicons. Review of personality and social psychology, 2, 141-165.

Marody, M. (1976). Sens teoretyczny a sens empiryczny pojęcia postawy. Analiza metodologiczna zasad doboru wskaźników w badanich nad postawami. Warszawa: Wydawnictwo Naukowe PWN.

Nelson, T. (2002). Psychology of prejudice, $1^{\text {st }}$ edition. Boston: Allyn \& Bacon.

Pietrulewicz, B. \& Wolska, A. (2008). Attitudes Toward People with Mental Illness (stigma) in the Intercultural Context. Polish Journal of Social Science, 3, 213-240.

Ross, L. \& Nisbett, R.E. (1991). The person and the situation: Perspectives of social psychology. New York: McGraw-Hill.

Skinner, B.F. (1953). Science and human behavior. New York: Macmillan. 